\title{
The Concept of Minimalist Interventions in General Medicine: Minimum Means, Maximum Effect
}

\section{Jose Luis Turabian.}

Department of Specialist in Family and Community Medicine. Health Center Santa Maria de Benquerencia. Regional Health Service of Castilla la Mancha (SESCAM), Toledo, Spain.

Corresponding Author : Jose Luis Turabian, Study undertaken in the Specialist in Family and Community Medicine. Health Center Santa Maria de Benquerencia. Regional Health Service of Castilla la Mancha (SESCAM), Toledo, Spain. Email: jturabianf@hotmail.com

Received date: April 25,2019;Accepted date : May 16,2019; Published date: May 21,2019.

Citation: Jose Luis Turabian. The Concept Of Minimalist Interventions In General Medicine: Minimum Means, Maximum EffecT J. General medicine and Clinical Practice. Doi: 10.31579/2639-4162/2019/031.

Copyright : (c) 2019 Jose Luis Turabian. This is an open-access article distributed under the terms of The Creative Commons Attribution License, which permits unrestricted use, distribution, and reproduction in any medium, provided the original author and source are credited.

\begin{abstract}
Practical work requires deepening in the theory. In this way, the intention of this article is to systematize the concept of "minimal interventions", as well as draw attention to the impact that this type of interventions of the general practitioner can have on the patient, however small and insignificant, their action may seem. The doctor-patient relationship creates contexts that act, in one way or another, on the patient. There is no absence of medical intervention, even when there is no conscious intervention of the doctor on the patient. Non-intervention is a type of intervention. Non-intervention is a bio-fiction. The different types of doctor-patient relationship give rise, naturally, perhaps imperceptibly, to different models of educational intervention. In this scenario, a conceptualization and systematization of the "micro-interventions" in general medicine is presented: minimal, imperceptible, briefs, low cost, zen, human size, opportunistic, small and mild, but continuous interventions. These micro-interventions are cost-effective no matter how small and insignificant their action seems. These minimal interventions of the general practitioner are of great importance and constitute an updated form of the "less is more" rationalist, they express the power of the minimum gesture in general / family medicine, and can transform health / disease on a large scale. In this way we can hypothesize a plausible relationship between the minimal but concentrated and powerful means, that is to say "contextualized", and the intensity of the effect in general medicine. The clarity of the reading of a message depends on the appreciation of the context; what counts is not what, but how. The context highlights or "pulls" the message. Many small people, in small places, doing small things, can change the world.
\end{abstract}

Keywords: family practice; general practice; interview; communication; brief psychotherapy; motivational interviewing; cognitive therapy; humanism.

"For him, the most beautiful picture in the world is in Siena in Italy. It's a tiny landscape by Amgrogio Lorenzetti, scarcely longer than the palm of a hand."

Saramago J (2002 ) Journey to Portugal: A Pursuit of Portugal's History and Culture. London: The Harvill Press.

\section{INTRODUCTION}

Just as humans are organically incapable of noticing the minor movements of reality, and therefore we conceive as still bodies whose movement we do not perceive, but, analyzed better, we find that what we perceive immobile always moves internally and externally. And so, many traditional notions such as: stillness, rest, or stability, are very dependent on our perceptual inabilities to notice small speeds. In the same way, there is no absence of medical intervention, even when there is no conscious intervention of the doctor on the patient. "Nonintervention" is a type of intervention. Non-intervention is a biofiction. Whenever the scale of analysis of a reality, apparently still, without any intervention, is reduced, it is verified that movement or intervention exists at its lowest scales. What we categorize as still, without suffering any intervention, depends on the threshold of perception that we use (1).

The doctor-patient relationship has been and remains a keystone of care: it is the medium in which data are gathered, diagnoses and plans are made, compliance is accomplished, and healing, patient activation, and support are provided [2,3]. In family medicine, the type of doctor-patient relationship and its continuity over months or many years generates a context of intervention, of which we may not be aware.

There are three types of doctor-patient relationship that are frequently used with the patient [4-6], and these different types of doctor-patient relationship give rise, naturally, perhaps imperceptibly, to different models of educational intervention [7-9].
TABLE 1 shows a general outline of this relationship between models of communication and education.

\begin{tabular}{|c|c|}
\hline $\begin{array}{l}\text { Type of doctor-patie } \\
\text { relationship }\end{array}$ & $\begin{array}{l}\text { onal } \\
\text { ne }\end{array}$ \\
\hline $\begin{array}{l}\text { 1.-Active-passive relationship: } \\
\text { the patient, because of his } \\
\text { pathology, participates very little } \\
\text { in the relationship. The doctor } \\
\text { behaves with the patient as a } \\
\text { father would with his son who is } \\
\text { a few months old. The doctor is } \\
\text { the one who manages the } \\
\text { situation totally. It may be } \\
\text { adequate in acute stages, } \\
\text { especially if there is some degree } \\
\text { of decreased consciousness }\end{array}$ & $\begin{array}{l}\text { 1.-Informative Model: information } \\
\text {-Goals: achieve knowledge; } \\
\text { educational contents of the patient's } \\
\text { curriculum to which the must adapt } \\
\text {-Indicators: knowledge about health } \\
\text { / disease } \\
\text {-Health outcomes: reduction of } \\
\text { morbidity and mortality } \\
\text {-Methods: lectures, classes, } \\
\text { informative messages, etc. }\end{array}$ \\
\hline $\begin{array}{l}\text { 2.-The most frequently used is } \\
\text { the type of "guided cooperation" } \\
\text { relationship: the patient can } \\
\text { receive guidance and cooperate } \\
\text { in their treatment. The doctor } \\
\text { behaves like a father in front of a } \\
\text { teenage son. It pursues ties that } \\
\text { guarantee the realization of the } \\
\text { appropriate treatment. }\end{array}$ & $\begin{array}{l}\text { 2.-Persuasive: information plus } \\
\text { motivation } \\
\text {-Goals: achieve behaviors that } \\
\text { prevent diseases. } \\
\text {-Indicators: reduction of smoking, } \\
\text { increase in exercise, etc. } \\
\text {-Health outcomes: reduction of } \\
\text { morbidity and mortality. } \\
\text {-Methods: campaigns in the media, } \\
\text { persuasive medical advice, etc. }\end{array}$ \\
\hline
\end{tabular}




\begin{tabular}{|l|l|}
\hline $\begin{array}{l}\text { 3.-Relationship of } \\
\text { "mutual }\end{array}$ & 3.-Participatory: information plus motivation \\
participation". & clus training starting from the needs and the \\
The doctor should & -Goals: increase individual control over your \\
discuss with the & health. \\
patient his & - Indicators: increased decision-making, coping \\
management of & with problems, assertiveness,self-responsibility, \\
the disease and of & collaboration, creativity, etc. \\
the situations that & Results: increase of psycho-social status, \\
create anxiety. & development, training (power), positive health. \\
& -Methods: discussion, dialogue, groups, \\
& games,simulations,collective problem solving \\
& case studies, community development, etc. \\
\hline
\end{tabular}

Table 1: The Different Types of Doctor-Patient Relationship Give Rise, Naturally, Perhaps Imperceptibly, To Different Models of Educational Intervention.

Source: self made

On the other hand, the family doctor is like a catalyst: "a small amount" of it, when present in the chemical reaction, can produce great results. Thus, the family doctor continuously performs interventions that we can call "micro or nano-interventions": minimum interventions such as, to stop smoking, lose weight, dental hygiene, psychotherapy, etc., which in reality are "maximum" because of their great effects.

Let's use the metaphor of quantum physics to illustrate this effect. In quantum mechanics, the physical phenomena of infinitely small scales act differently from that of larger scales. These interventions or behaviours contain a diverse multiplicity of states. In general, quantum physics does not predict a single result of each observation but quite the opposite. A series of imperceptible changes are generated that configure different apparently fragmented topographies, but that in turn gather to create a single integrity of multiple readings, often of great power.

In this scenario, a conceptualization and systematization of the "micro-interventions" or "minimalist interventions" in general medicine is presented: minimal, imperceptible, briefs, low cost, zen, human size, opportunistic, small and slightly, but continuous, interventions, with the intention of calling the attention on the impact caused by the action of the general practitioner on the patient, however small and insignificant their action may seem, and emphasize the importance of this updated form of "less is more", or the "power of the minimum gesture" in general medicine / family medicine.

\section{DISCUSSION}

Primary health care professionals are in an excellent position to identify, screen, and conduct brief interventions for patients (10). Many are the terms that appear in the bibliography in relation to the micro-interventions. An approach to the classification, conceptualization and systematization of these "micro-interventions" is presented in the TABLE 2.

\begin{tabular}{|l|l|l|}
\hline $\begin{array}{l}\text { Types } \\
\text { "Minimalist" } \\
\text { Nterventions } \\
\text { Overlap } \\
\text { Other) }\end{array}$ & Each & Concept \\
\hline $\begin{array}{l}\text { 1. Brief } \\
\text { interventions }\end{array}$ & $\begin{array}{l}\text { Brief interventions aim to identify current or } \\
\text { potential problems and motivate those at risk to } \\
\text { change their behaviour (range from 5 minutes } \\
\text { of brief advice to 15-30 minutes of brief } \\
\text { counselling). Generally, brief interventions are } \\
\text { not intended to treat people with serious health } \\
\text { problems; however, they are a valuable tool for } \\
\text { treatment for problematic or risky behaviours. } \\
\text { Common 2ehavioural therapies used as brief } \\
\text { counselling are brief versions of cognitive } \\
\text { 2ehavioural therapy and motivational } \\
\text { interviewing, or some combination of the two. }\end{array}$ \\
\hline
\end{tabular}

\begin{tabular}{|c|c|}
\hline 2.Minimalist interventions & $\begin{array}{l}\text { Small verbal affirmations that generate } \\
\text { great therapeutic achievements. It } \\
\text { implies that interventions must be } \\
\text { limited to the circle of what is } \\
\text { indispensable (and generally it lasting } \\
\text { less than } 3 \text { minutes), in favor of the } \\
\text { tolerance of other circumstances; 'the } \\
\text { minimum that would have to be done } \\
\text { with great scope' }\end{array}$ \\
\hline $\begin{array}{l}\text { 3.Human-sized } \\
\text { interventions }\end{array}$ & $\begin{array}{l}\text { Therapist has an attitude of deep respect } \\
\text { and full acceptance of client as he is, } \\
\text { and towards the potential of the patient } \\
\text { to face himself in his situation to the } \\
\text { problem. These attitudes are } \\
\text { impregnated with a great affection } \\
\text { towards the core of the person, and in a } \\
\text { level of communication in which } \\
\text { patient, can begin to perceive that the } \\
\text { therapist he understands the feelings he } \\
\text { is experiencing and accepts it in the } \\
\text { depth of that understanding }\end{array}$ \\
\hline $\begin{array}{ll}\text { 4.Brief } & \text { Strategic } \\
\text { Interventions } & \end{array}$ & $\begin{array}{l}\text { It refers to the intervention "at the right } \\
\text { time to succeed". The therapy or } \\
\text { strategic intervention does not look for } \\
\text { the "deep" causes of the problem, since } \\
\text { what is considered is not the way in } \\
\text { which the problem has been formed in } \\
\text { the past, but how it remains in the } \\
\text { present. Small conversations can be used } \\
\text { as a diplomatic or tactical strategy, } \\
\text { through which you can avoid or address } \\
\text { unpleasant or sensitive issues indirectly }\end{array}$ \\
\hline $\begin{array}{l}\text { 5."Soft" interventions } \\
\text { ("zen") for hard problems }\end{array}$ & $\begin{array}{l}\text { This type of interventions is related to } \\
\text { "Mindfulness", and in this way } \\
\text { incorporates "soft" interventions (such } \\
\text { as the soft movements of some of the } \\
\text { yoga practices). The basic idea is that } \\
\text { the intervention can generate a positive, } \\
\text { creative and permanent learning attitude }\end{array}$ \\
\hline $\begin{array}{l}\text { 6.Imperceptible } \\
\text { interventions }\end{array}$ & $\begin{array}{l}\text { These "almost imperceptible" } \\
\text { interventions are small verbal } \\
\text { affirmations that generate great } \\
\text { therapeutic achievements and that help } \\
\text { overcome resistance to change and } \\
\text { strengthen the therapeutic relationship }\end{array}$ \\
\hline 7. Adapted interventions & $\begin{array}{l}\text { It is based on the power of word choice } \\
\text { to motivate or alienate patients and } \\
\text { parents during counselling }\end{array}$ \\
\hline 8. Low cost interventions & $\begin{array}{l}\text { Small interventions are essentially low } \\
\text { cost. Any small intervention that results } \\
\text { in an improvement in the broad sense of } \\
\text { the quality of life of its users is } \\
\text { considered effective and efficient. The } \\
\text { ultimate goal of medicine and public } \\
\text { health is to identify simple, cheap and } \\
\text { effective interventions that are able to } \\
\text { act successfully or prevent or reduce } \\
\text { health problems and the consequences } \\
\text { of the disease }\end{array}$ \\
\hline $\begin{array}{l}\text { 9. Small but continuous } \\
\text { interventions }\end{array}$ & $\begin{array}{l}\text { Repetition of simple messages makes an } \\
\text { educational intervention more effective. } \\
\text { Continuity of care (which is a mayor } \\
\text { characteristic of general medicine) is the } \\
\text { substrate that allows the repetition of } \\
\text { messages making an adequate use of } \\
\text { human and natural resources in general } \\
\text { medicine }\end{array}$ \\
\hline
\end{tabular}

Table 2: An Approach to the Systematization and Conceptualization of "Minimalist" Interventions in General Medicine. 
Using a non-judgemental approach and good listening skills, the general practitioner seeks to understand whether patients are aware of the potential consequences of their behaviour on their own health and wellbeing, how they are motivated to change, what barriers to change are, and what support they might need (16). In summary, there is a growing focus on socalled "brief interventions" which are time-limited with a particular focus on the individual treatment seeker and patient current situation (17-19).

\section{Minimalist interventions}

This is minimal intervention, usually with duration less than 3 minutes. They are small verbal affirmations that generate great therapeutic achievements. It implies that interventions must be limited to the circle of the indispensable, in favour of the tolerance of other milder circumstances; "the minimum that would have to be done with great scope". What be judged as the "acceptable" minimum will be variable due to the differences in resources availability. The "minimalist concept", in a general way, is that things that have been reduced to the essential and the excess materials are removed; all being reduced to the essential, without leftover elements that fill without a sense (20).

We can look at the example of minimalist art: a contemporary artistic movement which emerged in the United States, during the decade of the $60 \mathrm{~s}$, in the twentieth century, which has the tendency to reduce their works to the fundamental, using only the minimum and basic elements, therefore only have representations of essential and fundamental things for the artist, who uses the elementary geometry of the forms, seeking the most expressiveness with the minimum resources, being critic to the excess. Minimalist art has been influenced by oriental traditions, such as Japanese, tending to the reduction of elements and the economy of resources.

Minimalism allows most variations towards Zen and Orientalism art. An example of this could be the use of a natural fabric, simple geometric shapes or pure colours. The minimalist art is not only reduced to painting and music, but also to sculpture, design, architecture and furniture, for example, In this sense, today it is common to find minimalist trends, even in decoration of houses and interior spaces, such as rooms, kitchen or furniture. Following these criteria, TABLE 3 shows minimalist interventions characteristics

\section{Table 3: Minimalist Interventions Characteristics}

1.-Austerity in the intervention and absence of unnecessary "ornaments"

2.-Maximum simplicity

3.-Messages manipulated as little as possible.

4.-Play with the creation of patient-context contrasts (message is especially highlighted about the specific context of the patient), such as minimalist art could play with "bright-matte", "soft-rough", "opaquetransparent", or "coarse-fine"

5.-Pure or direct messages

6.-Single messages (not several messages together)

7.-Repetitions of messages, which are usually short and with few variations (as in minimalist music)

Source: self made

\section{Human-sized interventions}

It's about helping the "the process of becoming a person": If the therapist has within himself, an attitude of deep respect and full acceptance of the client as he is, and towards the potential of the patient to face himself in his situation to the problem, and if these attitudes are impregnated with a sufficient heat, with great affection towards the core of the person, and if a level of communication is achieved, so that the patient, can begin to perceive that the therapist he understands the feelings he is experiencing and they are accepted it in the depth of that understanding, so, we can be sure that the process is already underway.

It is difficult, nowadays, to realize the impact that this simple formulation has had. Its revolutionary implications include the possibility that almost all training in psychotherapy was, at best, redundant and even harmful. The emphasis on the human dimension of medicine requires a reorientation of the priority values: community, ecology, tolerance with alternative lifestyles, equality, "the small is beautiful" - human-sized medicine, personal growth, etc. 
Human and social problems can not always be resolved through technology, nor can they be reduced to "personal problems" due to bad health habits (21).

Individual and social health can only be improved if decisions are made by people who:

-They relate directly with each other

-They understand the relevance of decisions in their lives

-Decisions are made on a human scale

People can change the system just by thinking about human-scale decision making at a level where there can be interactions between people. Understanding the scale of human activities is fundamental, and this scale is one in which collaboration / cooperation, dialogue and interaction between people can take place.

Table 4 presents the concepts of the "human" strategy of "small is beautiful".

Table 4: The Strategy of "Small Is Beautiful" Is Based On

1.-Add value to the "micro" -the level where the patient lives

2.-Better knowledge of the context

3.-Searching coalitions and cooperation in health

4.-Better understanding of meanings for the patient

5.-Better levels of patient participation

6.-Promote communication, empathy and compassion in health-patient relationships, integrating the professional visions of patients and citizens.

Source: self made

The technologies of "small is beautiful" are specific to general medicine and allow the increase of our efficiency (capacity to attend well at a reasonable cost), for which it is necessary to "understand" patients in their contexts, that is, To be more efficient (and also more effective) is to contextualize better and more deeply. All this implies the development of a new patient model responsible for their health (22-25).

\section{Brief Strategic Interventions}

It refers to the intervention "at the right time to succeed". The therapy or strategic intervention does not look for the "deep" causes of the problem, since what is considered is not the way in which the problem has been formed in the past, but how it remains in the present. It is more a knowing how, than a knowing why; that is, we observe how the problem that occurs within the relational system works, focusing on the present interaction and on the observable behaviours that maintain the problem. In other words, how the subject has tried, up to now, to combat or solve the problem and how it is possible to change this problematic situation in the fastest and most effective way. This approach breaks with the belief that problems that persist for a long time necessarily require an equal treatment of long and stormy. The therapy or strategic intervention is not a superficial and symptomatic intervention, but a radical intervention since it aims at the restructuring of the ways in which each one constructs the reality that then confronts, it is therefore to construct therapeutic realities.

From a strategic perspective, only after the change or the new learning has taken place, can knowledge repeat and apply it again; that is, the way of acting is change first the action, and as a consequence of this changes the way of thinking or the framework of the patient's reality. It is intended to change the current situation, and once such a change is established, no matter how small, other minor changes can be made and a snowball effect of these minor changes leads to more important ones $(26,27)$. A behaviourally-informed, very brief, physiciandelivered opportunistic intervention is acceptable to patients and it is an effective way to change behaviours, such as problems related with family cycle transitions, or reduce weight (28).

Small conversations can be used as a diplomatic or tactical strategy, through which you can avoid or address unpleasant or sensitive issues indirectly.

Auctores Publishing - Volume1-031 www.auctoresonline.org

Page - 04
For example, when surrounding a certain topic, or referring indirectly to a certain explanation that the patient has to give (for example, regarding lack of compliance with the treatment, etc.), is giving the patient the opportunity to admit and explain, but without this appearing as a direct challenge that could have been seen as punitive. They can be a time when a small talk is used to avoid a "big talk".

\section{5. "Soft" interventions ("zen") for hard problems}

The word soft may sound weak, inconsistent, without a scientific framework, or as an "extra", something to adorn a proposal whose foundation is in something else.

The difference starts from a historical division between hard and soft sciences, possibly from the exaltation of the positivism of the experimental sciences over the theoretical sciences, and from the physical and biological laws over the philosophical constructions, attributing to the natural sciences extreme qualities of rationality and empiricism that do not always reach in practice. In fact, the soft sciences deal with hard problems (human existence, the meaning we attribute to it, the deep motivations of behavior) while the hard sciences deal with soft problems (inanimate objects, natural phenomena). This type of interventions is related to "Mindfulness", and in this way incorporates "soft" interventions (such as the soft movements of some of the yoga practices). The basic idea is that the intervention can generate a positive, creative and permanent learning attitude (29).

\section{Imperceptible interventions}

These are interventions of smooth, slow, and gradual movements that are almost imperceptible. These are "minimal" interventions to achieve the maximum effect in the treatment and psychological counselling. They require linguistic models of effective and efficient communication with patients in the counselling and consultation sessions. These "almost imperceptible" interventions are small verbal affirmations that generate great therapeutic achievements and that help overcome resistance to change and strengthen the therapeutic relationship (30).

The doctor can, towards the end of the visit, ask a general question, such as "Good, so what have you got organized for today?" With the word "good" followed by a brief pause, the end of a topic and the beginning of other is indicated This way, the doctor indicates that the essential purpose of the visit is over, and you enter into a topic that seems informal and friendly and a prelude to closing the conversation, but the doctor can use it in a certain way, subtle and expert to establish a connection with the patient, obtain clinical information, and perform a minimalist intervention, in a very short time. For example, in a patient who is visited after surgery in ulcerative colitis, she may respond that "your friend has a day off from work, so they probably do some errands and watch a movie. "From this answer, you can get an idea of the patient's energy levels, mood, social network and confidence, since all these variables are significant markers of convalescence and patient recovery.

Something similar happens when, practically without preliminaries, patient enters to consulting room and doctor asks "Is it a smile?" This observation of extremely economic opening fulfils many functions: it is a variant of "How are you?", but it is more than a greeting; here, you get information from the patient, determining if things were going well or not, and by doing this, you can also measure the effectiveness of the treatment or the advice given in the previous visit (31).

\section{Adapted interventions}

It is based on the power of word choice to motivate or alienate patients and parents during counselling. For example, for advice about obesity, Latino parents find some descriptions of weight motivating and other offensive. Latino children are disproportionately affected by obesity, but are less likely than non-Latino children to receive guidance on obesity. The most desirable / motivating and least offensive terms in English are "unhealthy weight" and "too much weight for your health"; the corresponding terms in Spanish are "demasiado peso para su salud" and "demasiado peso para su edad." The commonly used clinical terms "high BMI" and "overweight" are often non-motivating both in English and in their translation into Spanish. Finally, parents become very offended by "chubby", "fat", "gordo," and "muy gordo." 
Therefore, we must remember that our clinical jargon or attempts to use colloquialisms in health counselling can be perceived in a way that motivates or empowers patients or parents. This not only happens with obesity, but it happens with the whole spectrum of medical problems, such as mental health, food, use of media or discipline. A good start for the tailored intervention may be to ask patients or parents what terms they prefer, and using these terms consistently (32).

\section{Low cost interventions}

Educational interventions have to be effective, but in addition, factors such as fidelity, sustainability, viability and profitability of the intervention must be considered. Moreover, special attention should be given to intervention modalities that could be effective in lowresource settings (33). Small interventions are essentially low cost. Any small intervention that results in an improvement in the broad sense of the quality of life of its users is considered effective and efficient. The ultimate goal of medicine and public health is to identify simple, cheap and effective interventions that are able to act successfully or prevent or reduce health problems and the consequences of the disease (34). In this framework, the reviews of the effectiveness of small educational interventions show positive results, such as a significant reduction in the incidence of diabetes through lifestyle interventions in patients with oral glucose intolerance (35).

\section{Small interventions, but continuous interventions}

Continuity of care is a characteristic of general medicine, which is defined in terms of relationships, rather than in terms of diseases or technology. The continuity of relations between the family doctor and the patients in their environment, even in an implicit way, builds trust and creates a therapeutic context, and allows the doctor to use the available time more productively $(36,37)$. Likewise, the concept of "prevention" is important in medicine, especially in family medicine. The conceptual basis of these tasks is "opportunistic prevention", because every contact with patients provides opportunities for the prevention of illness and the encouragement of people to adopt more healthy life-styles, even when the patient has come to consultation for an apparently unrelated problem, which has to be dealt with first (38). On the other hand, repetition as a learning method is a natural and effective way. The repetition of simple messages makes an educational intervention more effective (39). In this way, the continuity of care is the substrate that allows the repetition of messages making an adequate use of human and natural resources in general medicine (40).

\section{CONCLUSION}

Diagnosis and treatment in medicine is a matter of scale. It is about making the decision-making process at an appropriate scale. The family doctor is like a "little enzyme" that looks insignificant at first sight, but on which depends the rhythm and speed of a chemical reaction. Our task as general practitioners / family physicians is a minimal, humble, but very important task: to discover what is between the interest of the people for health and to know what we can do to make health happen, favouring that individual is in a better position to advance toward his health, using the minimum effort by us. The work of the family doctor resembles that of a powerful reagent. Its presence is never dominant, it is always prudent, and adapted to the demands of each situation, and this is evident in the speed and quality of the results (41).

In popular perception, the "small talk or intervention" is seen as formulaic, peripheral, trivial, minor or unimportant. However, the idea that the small talk is not important has been questioned by others who show that small talks can play a key role in promoting interpersonal and, at times, transactional objectives. As a limitation, it can be cited, that some functions of the small talk seem ambiguous or contradictory; for example, a small talk may allow speakers to approach or avoid discussion of more serious issues (31). On the other hand, it is hypothesized that the general practitioner who performs small-scale interventions in a continuous way, experiences fewer symptoms of exhaustion, less physical demand, and less workload (42).
Finally, an analogy could be drawn between the minimalist interventions in general medicine and minimalist art, which can be illustrate by the work of the painter Josef Albers (43): it is the result of a true "economy of form" and a decided will of simplicity with the productive use of means and resources intentionally limited which gives rise to explosions of colour, with great material content and high poetic and spiritual content; so, the goal in art and in life (and in general medicine) is to achieve the "maximum effect" through the "minimum of means." (FIGURE 1)

\section{FIGURE 1. MINIMUM MEANS, MAXIMUM EFFECT}

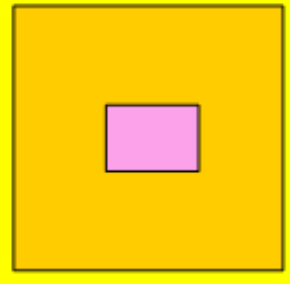

Source: self made (imitation of the way of the painter Josef Albers)

In this way we can hypothesize a plausible relationship between the minimal but concentrated and powerful means, that is to say "contextualized", and the intensity of the effect in general medicine. The clarity of the reading of a message depends on the appreciation of the context; what counts is not what, but how. The context highlights or "pulls" the message (FIGURE 2).In short, practical work requires deepening in the theory, and many small people, in small places, doing small things, can change the world.

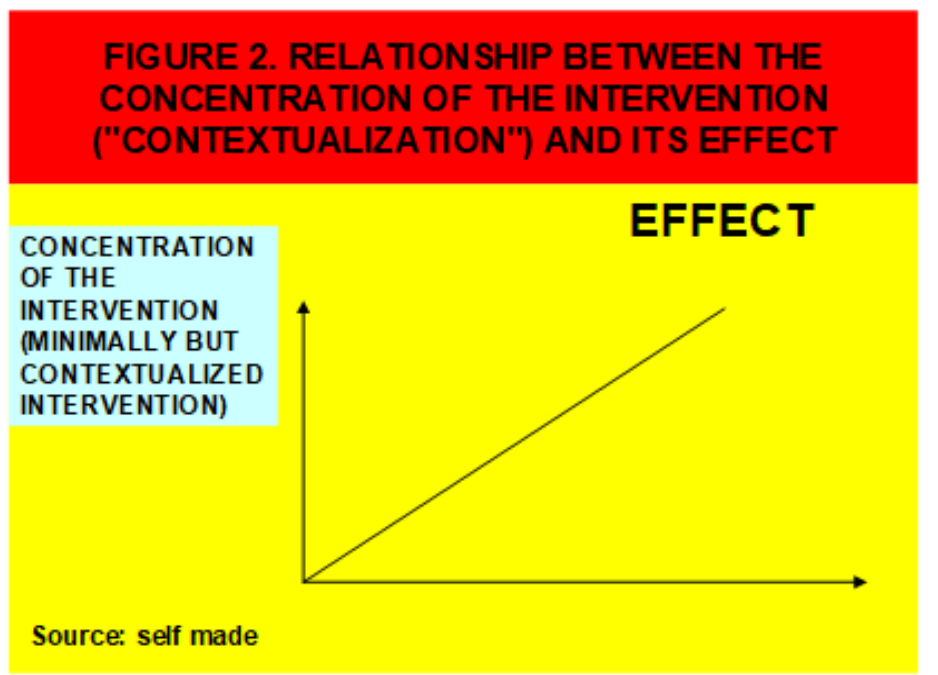

In short, practical work requires deepening in the theory, and many small people, in small places, doing small things, can change the world.

\section{REFERENCES}

1. Bardier D El movimiento de lo quieto (Primera parte) [Homepage in Internet].

2. Goold SD, Lipkin M (1999) The Doctor-Patient Relationship: Challenges, Opportunities, and Strategies. J Gen Intern Med; 14(Suppl 1):S26-33.

3. Turabian JL, Perez Franco B (2008) The Effect of Seeing the Sea for the First Time. An Attempt at Defining the Family Medicine Law:The Interview is Clinical Medicine. Aten Primaria; 40:565-6.

4. González Menéndez R (1979) Psicología para médicos generales. Ciudad de La Habana, Cuba: Editorial Científico-Técnica. 
5. Turabian JL (2017) The Interview with the Pregnant Woman. Gynecol Obstet; 7: e124. https://www.omicsonline.org/peerreviewed/the-interview-with-the-pregnant-woman-94873.html

6. Turabian JL (2017) Physician-Patient Relationship in Obstetrics and Gynecology. Gynecol Obstet; 7:e123.

7. Turabián JL, Pérez-Franco B (2006) Too many theories of health promotion? Med Clin (Barc); 126(5):198.

8. Turabián, J L, Pérez Franco, B (1998) Advice of the general practitioner and healthy life styles: is there an alternative to passivity caused by technical and ethical difficulties? Med Clin (Barc); 110(5): 45.

9. Turabian J, Perez Franco B (1995) Del consejo médico persuasivo al participativo en Medicina de Familia. Elementos para iniciar un debate. [From persuasive medical advice to participatory in Family Medicine. Elements to start a debate] MEDIFAM; 5(5):258-63.

10. Albright G, Bryan C, Adam C, McMillan J, Shockley K (2017) Using Virtual Patient Simulations to Prepare Primary Health Care Professionals to Conduct Substance Use and Mental Health Screening and Brief Intervention. J Am Psychiatr Nurses Assoc; 4(3): 247-59.

11. Commonwealth of Australia. Department of Health (2004) Module 9: Working with young people on aod issues: facilitator's guide. 6.1 Brief interventions-a definition.

12. The SAMHSA-HRSA Center for Integrated Health Solutions. Brief interventions. [Homepage in Internet].

13. Poznyak V, Monteiro M, Humeniuk R, Ali R (2003) Brief intervention for substance use: Brief intervention for substance use: A manual for use in primary care a manual for use in primary care. WHO. Draft Version 1.1 for Field Testing.

14. Brief intervention. Wikipedia. [Homepage in Internet].

15. McPherson $T$, Goplerud E, Adam C (2015) Integrating adolescent substance abuse screening, brief intervention and treatment in health professions education. Addict Sci Clin Pract; 10(Suppl. 2): 1-2.

16. Fuller S (2015) Building brief intervention into your everyday work. Nurs Times; 111(5): 23-5.

17. Fiorentine R (1999) After drug treatment: are 12-step programs effective in maintaining abstinence? Am J Drug Alcohol Abuse; 25(1): 93-116.

18. Miller WR, Rollnick S (2002) Motivational interviewing: Preparing people for change. 2nd ed. New York: Guilford Press.

19. FDI (2002) Intervención mínima en el tratamiento de la caries dental. Declaracion de principios de la FDI. [Homepage in Internet].

20. Guía de tratamiento del tabaquismo. Barcelona: Sociedad Española de Neumología y Cirugía Torácica (2010) US Public Health Service. Intervenciones clinicas sobre el tabaquismo.

21. Cogswell BE, Sussman MB (Editors) (1982) Family Medicine: A new approach to health care. New York: The Haworth Press.

22. Skrabanek P (1998) The death of humane medicine. Humane medicine and the rise of coercive healthism. The Social Affairs Unit. Bury St Edmunds, Suffolk: St Edmundsbury Press Ltd.

23. Turabian JL (2003) Una medicina a escala humana. [A medicine on a human scale]. JANO; LXV (1489):10.

24. Carpintero E (2007) La medicalización de la vida cotidiana. [The medicalization of everyday life]. Revista Topía; Abril.
25. Permanyer-Miralda G, Ferreira-González I (2006) Towards evidencebased medicine perversion? Med Clin (Barc); 126: 497-9.

26. Terapia Breve Estratégica (2018) Tàndem Psicoterapia. [Homepage in Internet].

27. Hewitt Ramírez N, Gantiva Díaz CA (2009) Brief therapy: an alternative for effective psychological intervention. Avances en Psicología Latinoamericana/Bogotá (Colombia); 27(1): 165-76. http://www.redalyc.org/pdf/799/79911627012.pdf

28. Aveyard P, Lewis A, Tearne S, Hood K, Christian-Brown A, Adab P, et al. (2016) Screening and brief intervention for obesity in primary care: a parallel, two-arm, randomised trial. Lancet; 388(10059): 2492-500.

29. Vásquez-Dextre ER (2016) Mindfulness: General concepts, psychotherapy and clinical applications. Rev Neuropsiquiatr; 79(1).

30. Prior M (2011) Minimáximas-15 intervenciones mínimas de efecto máximo para la terapia y el asesoramiento. Barcelona: Editorial HERDER.

31. Macdonald LM (2016) Expertise in Everyday Nurse-Patient Conversations. The Importance of Small Talk. Glob Qual Nurs Res.

32. Knierim SD, Newcomer S, Castillo A, Rahm AK, Raghunath S, Clarke C, et al. (2018) Latino parents' perceptions of pediatric weight counseling terms. Acad Pediatr; 18:342.

33. WHO (2018) Interventions on Diet and Physical Activity: What Works.

34. Estébanez P (2005) Medicina humanitaria. Madrid: Ediciones Díaz de Santos

35. Yoon U, Kwok LL, Magkidis A (2013) Efficacy of lifestyle interventions in reducing diabetes incidence in patients with impaired glucose tolerance: a systematic review of randomized controlled trials. Metabolism; 62(2): 303-14. https://www.ncbi.nlm.nih.gov /pubmed/22959500

36. Richards H (2009) We must defend personal continuity in primary care. BMJ; 339:b3923.

37. Stott NCH (1983) Primary health care. Bridging the gap between theory and practice. New York: Springer-Verlag.

38. Turabian JL (2017) Opportunistic Prevention in Family Medicine: Anticipatory Care, Case-Finding and Continuity of Care. J Health Care Prev 1: 101.

39. Marqués F, Saáz S, Guayta R (eds.) (2004) Métodos y medios en promoción y educación para la salud. Barcelona: Editorial UOC.

40. Schumacher EF (1990) Lo pequeño es hermoso. Madrid: Hermann Blume.

41. Turabian JL, Pérez Franco B (2001) Actividades Comunitarias en Medicina de Familia y Atención Primaria. [Community Activities in Family Medicine and Primary Care]. Madrid: Díaz de Santos. http://www.amazon.es/Actividades-comunitarias-medicinaatenci\%C3\%B3n-primaria/dp/8479784741

42. Zwakhalen SMG, Hamers JPH, van Rossum E, Ambergen T, Kempen GIJM, Verbeek H (2018) Working in small-scale, homelike dementia care: effects on staff burnout symptoms and job characteristics. A quasi-experimental, longitudinal study. J Res Nurs; 23(2-3): 109-22.

43. Albers J (1979) La interacción del color [Interacion of color]. Madrid: Alianza Editorial. 